O. V. PYLYPENKO, N. V. KHORIAK, S. I. DOLHOPOLOV, O. D. NIKOLAYEV

\title{
MATHEMATICAL SIMULATION OF DYNAMIC PROCESSES IN HYDRAULIC AND GAS PATHS AT THE START OF A LIQUID-PROPELLANT ROCKET ENGINE WITH GENERATOR GAS AFTER-BURNING
}

\author{
Institute of Technical Mechanics \\ of the National Academy of Sciences of Ukraine and the State Space Agency of Ukraine \\ 15 Leshko-Popel St., Dnipro 49005,Ukraine; e-mail: khoryak@i.ua
}

One of the key problems in the design of liquid-propellant rocket engines (LPREs) is the assurance of a trouble-free LPRE start. LPRE bench tryout is highly expensive, and emergency situations may have grave consequences (including engine and bench equipment destruction), Because of this, one of the main tools that allow one to predict the LPRE dynamic characteristics and start-up operation features at the design and tryout stages is mathematical simulation. One of the most important and complex problems in LPRE start simulation is the description of LPRE gas-liquid volume filling, processes caused by pump cavitation, and the kinetics of propellant ignition and burn-out in the gas generator and the combustion chamber. This paper presents a modified mathematical model of cavitating pipe dynamics, which keeps its structure and operability over a wide cavitation number range and in mutual transitions between the cavitation and the cavitation-free pump operation, which is required for the numerical study of working processes in an LPRE at its start. An approach to the construction of a nonlinear mathematical model of LPRE hydraulic path filling is presented. The approach allows one, if necessary, to automatically change the scheme of partitioning the hydraulic path into finite hydraulic elements in the process of its filling at engine start. A scheme of approximate substitution of delay equations in the mathematical model of LPRE gas path dynamics is proposed. The scheme is constructed with account for the features of calculation of LPRE start transients, and it allows the simulation accuracy to be improved with the minimum of model complication. The operability of the mathematical models developed is demonstrated by the example of simulating the start of a sustainer LPRE with oxidizing generator gas after-burning. The results of this study may be used in the mathematical simulation of the start of modern LPREs.

Keywords liquid-propellant rocket engine, start, transient, cavitation, inducer-equipped centrifugal pump, gas generator, transfer function, frequency characteristics, lagging element.

1. Belyaev E. N., Chervakov V. V. Mathematical Simulation of Liquid-Propellant Rocket Engines. Moscow: MAI-PRINT, 2009. 280 pp. (in Russian).

2. Solntsev V. L., Radugin I. S., Zadeba V. A. Basic requirements for main engines of advanced liquid-propelled super-heavy launch vehicles. Space Engineering and Technology. 2015. No. 2(9). Pp. 25-38. (in Russian).

3. Galeev A. G., Ivanov V. N., Katenin A. V., Liseikin V. A., Pikalov V. P., Plyakov A. D., Saidov G. G., Shibanov A. A. Methodology of Liquid-Propellant Rocket Engine and Propulsion System Bench Tryout, Basics of Test Operation and Test Bench Design [electronic resource]. Kirov: MTsNIP, 2015. 436 pp. URL: http://www.nic-rkp.ru/doc/metodologiya.pdf. (in Russian).

4. Katorgin B. I., Chvanov V. K., Belyaev E. N., Chervakov V. V. Mathemascal Simulation of processes in modern liquid-propellant rocket engines. Dvigatel. 2002. No. 4(22). Pp. 13-16. (in Russian).

5. Mechanical Engineering. Encyclopedia. In 40 vol. K. B. Frolov (Chf Ed.). Space Hardware. V. IV-22. A. P. Adzhyan, E. Akim, O. M. Alifanov et al.; V. P. Legostaev (Ed.) In 2 books. Book 1. Moscow: Mashinostroyeniye, 2012. 924 pp. (in Russian).

6. Liu Wei, Chen Liping, Xie Gang, Ding Ji, Zhang Haiming, Yang Hao Modeling and Simulation of Liquid Propellant Rocket Engine Transient Performance Using Modelica. Proc. of the 11th Int. Modelica Conf., 2015, Sept. 21-23, Versailles. France. p. 485-490. URL: www.ep.liu.se/ecp/118/052/ecp15118485.pdf of July 13, 2017.

7. Pylypenko O. V., Prokopchuk A. A., Dolgopolov S. I., Pisarenko V. Yu., Kovalenko V. N., Nikolaev A. D., Khoryak N .V. Pequliarities of mathematical modeling of low-frequency dynamics of the staged liquid rocket 
8. Lebedinsky E. V., Kalmykov G. P., Mosolov S. V. et al.; A. S. Koroteev (Ed.). Working Processes in a LiquidPropellant Rocket Engine and Their Simulation. Moscow: Mashinostroyeniye, 2008. 512 pp. (in Russian).

9. Di Matteo F., De Rosa M., Onofri M. Start-up transient simulation of a liquid rocket engine. AIAA 2011-6032 47th AIAA/ASME/SAE/ASEE Joint Propulsion Conference \& Exhibit (31 July - 03 August 2011), San Diego, California. 15 pp. URL: www.enu.kz/repository/2011/AIAA-2011-6032.pdf https://doi.org/10.2514/6.2011-6032

10. Shevyakov A. A., Kalnin V. M., Naumenkova M. V., Dyatlov V. G. Theory of Automatic Rocket Engine Control. Moscow: Mashinostroyeniye, 1978. 288 pp. (in Russian).

11. Pilipenko V. V., Zadontsev V. A., Natanzon M. S. Cavitation Oscillations and Hydrosystem Dynamics. Moscow: Mashinostroyeniye, 1977. 352 pp. (in Russian).

12. Pilipenko V. V. Cavitation Self-Oscillations. Kiev: Naukova Dumka, 1989. 316 pp. (in Russian).

13. Pilipenko V. V., Dolgopolov S. I. Experiment-and-calculation determination of the coefficients of an equation of cavity dynamics in inducer-equipped centrifugal pumps of different standard sizes. Teh. Meh. 1998. No. 8. Pp. 50-56. (in Russian). https://doi.org/10.1016/S0262-1762(99)80457-X

14. Dolgopolov S. I. Hydrodynamic model of cavitation oscillation for modelling dynamic processes within pump systems at high cavitation number. Teh. Meh. 2017. No. 2. Pp. 12-19. (in Russian). https://doi.org/10.15407/itm2017.02.012

15. Dolgopolov S. I., Zavoloka A. N., Nikoilaev A. D., Sviridenko N. F., Smolensky D. E. Parametric determination of hydrodynamic processes in feed system of space stage in stopping and starting the cruise engine. Teh. Meh. 2015. No. 2. Pp. 23-36. (in Russian).

16. Glikman B. F. Automatic Control of Liquid-Propellant Rocket Engines. Moscow: Myashinostroyenie, 1974. 396 pp. (in Russian).

17. Pylypenko O. V., Prokopchuk A. A., Dolhopolov S. I., Khoryak N. V., Nikolaev A. D., Pisarenko V. Yu., Kovalenko V. N. Mathematical simulation and stability analysis of low-frequency processes in a mid-flight liquid-propellant engine with generator gas after-burning. Vestnik Dvigatelestroyeniya. 2017. No. 2. Pp. 34-42. (in Russian).

18. Gemranova E. A., Kolbasenkov A. I. Koshelev I. M., Levochkin P. S., Martirosov D. S. Ways of suppressing low-frequency oscillations in a liquid-propellant rocket engine in deep throttling. Trudy NPO Energomash Imeni Akademika V. P. Glushko. 2013. No. 30. Pp. 104า-110. (in Russian).

19. Khoriak N. V., Dolhopolov S. I. Features of mathematical simulation of gas path dynamics in the problem of the stability of low-frequency processes in liquid-propellant rocket engines. Teh. Meh. 2017. No. 3. Pp. 30-44. (in Russian). https://doi.org/10.15407/itm2017.03.030

20. Handbook on Automatic Control Theory. A. A. Krasovsky (Ed.). Moscow: Nauka, 1987. 712 pp. (in Russian).

21. Apresyan L. A. Pade approximants (review). Izvestiya Vuzov. Radiofizika. 1979. V. XXII, No. 6. Pp. 653674. (in Russian). https://doi.org/10.1007/BF01081220 